\title{
Procrastination in Recognizing the Rights of Domestic Workers in Ethiopia
}

\begin{abstract}
The 1960 Ethiopian Civil Code regulates domestic working conditions, and it largely depends on employers' sense of fairness. The Code provides insufficient protection to domestic workers and has failed to facilitate stable domestic labour contracts to the disadvantage of employers. The 2003 labour law (as amended) excludes domestic workers from its sphere of application other than promising that a special regulation will be issued. But there is procrastination in the enactment of the regulation. This article examines the legal gaps in regulating domestic workers, its gender effects and the tenability of the reasons behind the procrastination. To this end, the article examines various sources, including laws, interviews, reports, ILO conventions, and comparative experience of some foreign states. The negative perception over domestic work, misconception about the prospective domestic workers regulation and the absence of interest groups that promote the causes of domestic workers are the major causes of the procrastination on the issuance of a regulatory framework for domestic work. In the common interest of domestic workers and employers, it is argued that a regulation must be issued based on a legally-defined relationship, as opposed to the existing status relationship.
\end{abstract}

Mussie Mezgebo Gebremedhin *

\section{Key terms}

Domestic work, domestic workers, labour rights, Ethiopia

DOI http://dx.doi.org/10.4314/mlr.v10i1.2

\footnotetext{
* Mussie Mezgebo Gebremedhin, (LL.B, LL.M), former Federal Prosecutor (2009-April 2016), part-timer law lecturer and researcher. I wish to express my deep gratitude to Dr. Elias N. Stebek, and the internal and external anonymous assessors for their helpful comments. The author can be reached at<mussie313@gmail.com>.

Acronyms:

ACHPR African Charter on Human and Peoples Rights

ACRWC African Charter on the Rights and Welfare of the Child

CEDAW Convention on the Elimination of All Forms of Discrimination against Women

ENWP Ethiopian National Women Policy

FDRE Federal Democratic Republic of Ethiopia

GTP Ethiopian's Growth and Transformation Plan

ICCPR International Covenant on Civil and Political Rights

IESCR International Covenant on Economic, Social and Cultural Rights

ILO International Labour Organization

ISCO International Standard Classification of Occupations

MoLSA FDRE Ministry of Labour and Social Affairs

SDGs Post-2015 Sustainable Development Goals

UDHR Universal Declaration of Human Rights
} 


\section{Introduction}

The labour rights movement of the Industrial Revolution demanded an end to inhuman working conditions that treated workers as mere commodity. ${ }^{1}$ The success of the movement, though very slow and limited, became a model for other oppressed groups. Women, black people, persons with disabilities, immigrant workers, and other minority groups followed similar paths and have succeeded in gaining various labour rights. But a segment of the labour force remains hidden in private homes since all the movements have been concerned with public sphere labour relations i.e. 'outside the home'.

Masked prejudice and discrimination against domestic workers are considered to be a hindrance to the extension of labour rights. Indeed, in many circumstances the mainstream attitude of a society subtly perpetuates some unfavourable conditions. Peter Singer rightly opined that "If we have learnt anything from the liberation movements, we should have learnt how difficult it is to be aware of latent prejudice in our attitudes to particular groups until this prejudice is forcefully pointed out". ${ }^{2}$ Singer's view is observable by comparing the rights of domestic workers with others, because there is usually quick and sharp rejection of the rights followed by a claim of their incompatibility with the nature of domestic work. However, the incompatibility usually emanates from the latent prejudice with regard to rights of domestic workers.

A paradigm shift is therefore indispensable to fully understand the concern of domestic workers and extend labour rights to them. Under the international arena, labour rights were extended to domestic workers after successive campaigns of various groups; particularly, domestic workers' organizations throughout the globe with the adoption of the ILO's Convention No. 189 on Decent Work for Domestic Workers and the accompanying Recommendation No. 201 in 2011 (the 2011 Domestic Workers Convention). ${ }^{3}$ A number of foreign states had recognized labour rights of domestic workers even before the introduction of the 2011 Domestic Workers Convention. National and international domestic workers promoters were vital in influencing decision makers towards recognizing the rights of domestic workers.

\footnotetext{
${ }^{1}$ See, Lenard R. Berlanstein (ed) (1992), The Industrial Revolution and Work in Nineteenth Century Europe (London: Routledge), pp. 134-152.

${ }^{2}$ Tom Regan and Peter Singer (eds.) (1989), Animal Rights and Human Obligations (New Jersey: Prentice-Hall), p. 148.

${ }^{3}$ The 2011 ILO Convention No. 189 and Recommendation No. 201 on Decent Work for Domestic Worker.

$<$ http://srsg.violenceagainstchildren.org/sites/default/files/documents/docs/ilo_convention_ 189.pdf $>$ accessed on $2^{\text {nd }}$ December 2014.
} 
In contrast, the extension of labour rights to the whole labour force is an unfinished process in Ethiopia. Workers employed in the private sector and in public enterprises that are engaged in economic activities enjoy labour rights, although this does not apply to some specific groups such as private managers. ${ }^{4}$ Domestic workers are expressly excluded from the application of the Labour Proclamation No. 377/2003, as amended (the 2003 labour law). The condition of domestic workers is still regulated by the 1960 Ethiopian Civil Code (the 1960 Civil Code) until the Council of Ministers issues a special domestic workers' regulation pursuant to article 3(3)(c) of the 2003 labour law. ${ }^{5}$ However, the Council of Ministers has not yet issued the special regulation for over a decade since the enactment of the 2003 Labour Proclamation.

This article seeks to examine the legal gaps in regulating domestic workers, its gender effects and the tenability of the justifications behind the procrastination, while limiting its scope only to domestic workers working within Ethiopia. It examines a variety of sources, including legal documents, researches, academic literature, interviews, reports, ILO conventions and experience of foreign states to address the questions. In particular, key informants (a domestic workers' broker, and two officials from MoLSA and Addis Ababa Police Commission) were interviewed about the condition of domestic workers and the reasons for the delay in the enactment of regulations on domestic workers. Previous researches on the working and living condition of domestic workers in Ethiopia and elsewhere were also used to complement the data obtained from the interviews.

The first section of the article deals with the general issues in domestic work and domestic workers. It defines the term domestic work and domestic workers, and discusses the need for the regulation of domestic work, with particular attention to the relationship between domestic work and women, and the problem of workers and employers associated with domestic work. Section 2 provides the legislative response of ILO and some states to the condition of domestic workers in order to draw lessons that are relevant to Ethiopia with

${ }^{4}$ Managers are excluded pursuant to article 3(2)(c) of the 2003 labour law, and their employment relations are regulated by the 1960 Ethiopian Civil Code which provides relatively lesser benefits as compared to the 2003 labour law. Female managers further encounter the problem of accessing the minimum working conditions and benefits for women employees stipulated under the 2003 labour law.

${ }^{5}$ In this context, it should be noted that the purpose of the prospective domestic workers' regulation is not to specify in detail the provisions of the 2003 labour law for the purpose of effective implementation; rather it is considered to provide a separate regime for the regulation of domestic work through legislative delegation of power from the FDRE House of People Representation to the Council of Ministers. Hence, the failure to enact the regulation amounts to discrimination against domestic workers as they are excluded from the scope of the 2003 labour law that confers better employment rights. 
regard to the legal framework for the regulation of the condition of domestic workers. The third section deals with Ethiopia's response to the condition of domestic workers. It mainly examines the legal framework applicable to domestic workers as enshrined under the 1960 Civil Code. Moreover, it closely examines the gaps in Ethiopia's laws. Section 4 analyzes the obligation of the Ethiopian government to issue a domestic workers' regulation which meets the thresholds envisaged under human rights instruments, and various national policies.

I argue that the FDRE Council of Ministers should issue a domestic workers' regulation without delay pursuant to the 2003 labour law. The reciprocal rights and obligations are expected to be based on legally stipulated minimum standards, as opposed to the status relationship enshrined in the 1960 Civil Code so that it can - in the common interest of domestic workers and employers - be possible to minimize the vulnerability, abuse, harassment, violence and gender inequality.

\section{General Issues in Domestic Work and Domestic Workers}

\subsection{Definition and scope of domestic work and domestic workers}

The 1960 Civil Code uses the term domestic servant or in Amharic 'isinc,' instead of a domestic worker. However, the Code does not clearly define what domestic work is and who domestic servants are. The domestic and international socio-political realities of the 1960s might have influenced the Code to use the term domestic servant. This 'designation' has its own implications, if not everything about domestic workers. It could imply and dictate the manner and kinds of treatment a domestic worker could receive. The implication may relate to unfavourable conditions and treatments a servant traditionally faced in the context of a master-servant relationship which involved inferior levels of treatment and protection than provided to other groups of workers.

The 1960 Civil Code reflects a similar position. The Code largely permits the condition of domestic workers to be regulated by the conscience of the employers. It provides lower protection and benefits to domestic workers compared with that of the protection and benefits accorded to other groups of workers. The former pro-Marxist Ethiopian regime had banned the use of (servant) Ashker or Gered in reference to a domestic worker. Since then, Pn.

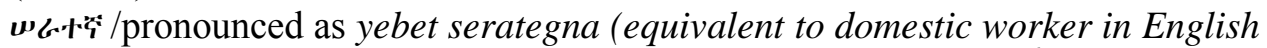
language)/ has been in use in lieu of the derogatory term 'Gered'. ${ }^{6}$ Even though

\footnotetext{
${ }^{6}$ Workers Federation of Ethiopia (1976), Annual Reports on Workers Status in Ethiopia, February 10, unpublished document, cited in Yohannes Mersha Belete "Challenges and Opportunities of Female Domestic Workers in Accessing Education: A Qualitative Study
} 
the Code is still in effect, the term domestic servant is - at present- considered as a derogatory term, - at least in formal communication.

The 2011 Domestic Workers Convention, which aims at the protection of workers performing domestic work within an employment relationship, defines domestic work and domestic workers. According to Article 1 of the Convention, "domestic work is work performed in or for a household or households". And, "domestic worker is defined as any person engaged in domestic work within an employment relationship". The Convention excludes any person who performs domestic work only occasionally or sporadically and not on an occupational basis from being treated as a domestic worker.

The definition involves two basic elements-being employed by and providing service for a private household. ${ }^{7}$ The service must be in connection with the work of a private dwelling-house which is intended to the satisfaction of a family or family-like situation, and its respective members. The work is carried out on behalf of the direct employer and under her/his authority, direction and supervision. It must also be done on a regular basis and in a continuous manner in return for remuneration; thus work of an accidental or discontinuous nature is not considered as domestic service. It is narrow in scope, since it excludes workers who provide care services in institutions such as orphanages, kindergartens, hospitals and old-age retirement homes. ${ }^{8}$

The formulation "in or for" a household or households assumes that the actual works are sometimes carried out outside the household premises such works as shopping, taking children to school, or serving a family during vacation. The terms "a household or households" also imply that domestic workers may work for multiple employers or be employed to perform domestic work in more than one household. A domestic worker may work on full-time or part-time basis; may live in the household of the employer (i.e. live-in worker) or reside in her/his own residence (i.e. live-out); and may be national or nonnational. On the other hand, the employer may be a member of the household or an enterprise that employs domestic workers and makes them available to various households. ${ }^{9}$

The Convention does not list down occupational categories or job descriptions that fall under domestic work. It leaves the kind of occupation or

\footnotetext{
of Bahir Dar City Administration, Amhara Regional State, Ethiopia" International journal of Sociology and Anthropology, 2014 Vol. 6(6), p. 193.

7 International Labour Organization (ILO) (2013), Domestic Workers across the World: Global and Regional Statistics and the Extent of Legal Protection (Geneva: ILO Publication), p. 8.

${ }^{8}$ Ibid.

${ }^{9}$ ILO (2011), Decent Work for Domestic Workers Convention 189 and Recommendation 201 at a Glance (Geneva: ILO Publications), p. 8.
} 
job description to be specified by member states within the definition given to domestic work. In this case, it is important to refer to the International Standard Classification of Occupations (ISCO) for determining the associated tasks and corresponding skill levels of domestic work. The ISCO recognizes domestic work under two broad classifications (major group 5 and 9). According to the classification, tasks performed in domestic work may include sweeping, vacuuming, cleaning, washing and polishing, ironing clothes, taking care of household linen, purchasing household supplies, cooking, serving foodprepared by them or others -and feeding persons who need help, taking care of children, or elderly or sick members of a family, gardening, guarding the house, and driving services to the family. ${ }^{10}$

\subsection{Important but undervalued: the paradox of domestic work}

The role of domestic work in securing the function and the well-being of families, enabling family members to be engaged in the labour market, and contributing to economic growth is apparent. This fact becomes increasingly important throughout the globe with structural changes such as labour market, gender relationships, economic growth, higher participation of women outside homes, and higher market competitiveness. ${ }^{11}$ Domestic work creates an opportunity of employment to the poor, rural women who have had little access to education, often with low employability. ${ }^{12}$ In Ethiopia, however, flow of remittance from urban to rural areas is almost non-existent mainly due to very low wage. ${ }^{13}$ Domestic work in foreign countries may also reduce unemployment in the global south countries. ${ }^{14}$

Nevertheless, domestic work is considered as devoid of value, exogenous to the labour market and receives low payment. Interlinked factors such as perception of domestic work as unproductive work, gender discrimination, and low bargaining power of domestic workers are considered as the explanation for

${ }^{10}$ ILO (2012) International Standard Classification of Occupations (ISCO-08): Structure, group definitions and correspondence tables (Geneva: ILO Publications), pp. 235 \& 337.

${ }^{11}$ See, for example, Einat Albin and Virginia Mantouvalou (2012), "the ILO Convention on Domestic Workers: From the Shadows to the Light", UCL Labour Rights Institute Working Papers-LRI WP 1. p 2, and ILO (2012), "Remuneration in domestic work: Conditions of Work and Employment Programme-Advancing decent work for domestic workers" Domestic Work Policy Brief No. 1, Geneva, ILO Office, p. 2.

12 Adamnesh Atnafu, et al (2014), "Poverty, Youth and Rural-Urban Migration in Ethiopia" Migrating out of Poverty Research Program Consortium Arts B, University of Sussex, Working Paper 17, pp. 8-9.

13 Id., p. 17.

${ }^{14}$ Asha D'Souza (2010), Moving towards Decent Work for Domestic Workers: An Overview of the ILO's Work (Geneva: ILO Bureau for Gender Equality, ILO Publications), pp. 6-7. 
the devaluation of domestic work. ${ }^{15}$ The lack of recognition of domestic work as a form of employment is evidenced in the terminology used and the very exclusion of it from labour laws that provide protection to workers. For example, even if the term "servant" - as stated earlier - is currently in the course of being considered as a derogatory term, it has not yet disappeared from usage in Ethiopia. The exclusion of domestic work from the 2003 labour law can be taken as the extension of the historical and systematic marginalization of women's work. As ILO notes, “... since domestic work is often regarded as an extension of women's traditional unpaid household and family responsibilities, it is still mostly invisible, undervalued and unprotected." 16

In response to the social devaluation of domestic work, feminists have developed the concept of 'reproductive labour' and contend that women play key roles in the capitalist mode of production as their paid or unpaid domestic works enable the continued maintenance and production of labour power. The raising of children and the maintenance of workers largely benefit from the unpaid work of women. ${ }^{17}$

\subsection{Feminization of domestic work}

In most societies, domestic work is devalued and relegated to women. It is a form of labour that was traditionally performed by the wife and mother without pay and was considered to be external to the productive economy. ${ }^{18}$ Since mothers and housewives do domestic work for no pay, domestic work is usually given little or no economic value and in most cases, it is considered as inherently unskilled and an essential part of women's responsibility. As some feminists claim, domestic work is not considered as real work since it is outside the boundary of the world's economy as men see it. ${ }^{19}$

${ }^{15}$ ILO, supra note 7.

16 ILO (2009), Gender Equality at the Heart of Decent Work: International Labour Conference Sixth Item on the Agenda (Geneva: 99th Session, International Labour Office), p. 36.

${ }^{17}$ Bridget Anderson (2001), "Reproductive Labour and Migration" Paper presented at the Sixth Metropolis Conference, Rotterdam, 26-30 November 'unpublished', p 5; Paddy Quick (2008), "Unpaid, Reproductive, Caring Labor?, The Production of Labor Power?, Theoretical and Practical Implications of Terms Used for Women's Work" Review of Radical Political Economics, Vol. 40, No. 3, Summer 2008, pp. 308-314.; and Lourdes Benería (1979), "Reproduction, production and the sexual division of labour" Cambridge Journal of Economics Vol. 3, No. 3 (September 1979), pp. 203-225.

${ }^{18}$ Philippa Smales (2010), The Right to Unite: A Handbook on Domestic Worker Rights Across Asia (Manila: Asia Pacific Forum on Women, Law and Development (APWLD), p. 11.

19 Taunya Lovell Banks (1999), "Toward a Global Critical Feminist Vision: Domestic Work and the Nanny Tax Debate" Journal of Gender, Race and Justice Vol. 3/99, p. 6. 
Domestic work was further devalued with the introduction of slave trade and engagement of slaves as domestic servants. This had enabled slave owner families, particularly wives and mothers, to pass their traditional responsibilities of domestic work to slave women. ${ }^{20}$ This condition thus added racial element to domestic work, even though it largely remained a feminized job. For instance, domestic work is a relegated job to women in Ethiopia. But the introduction of slave trade in Ethiopia attached another element with domestic work, under which slave women used to serve households, especially, in grinding cereals, gathering wood and fetching water by replacing the traditional responsibility of their master women. ${ }^{21}$ Likewise, enslaved African in the United States used to work in the homes of plantation owners, caring for their families and children. ${ }^{22}$

Subsequently, the massive liberalization of the global community after the second half of the twentieth century has entailed a new class-based domestic work relationship. For instance, when the early demand for equality rights resulted in empowering more women to compete with men in the public sphere (thereby turning them away from domestic responsibilities), a new class-based dimension of domestic work occurred. ${ }^{23}$ This class relation is formed according to the wealth status of the role players in a domestic work. During the past few decades, most of the burden of domestic work has thus passed onto women of lower economic status, particularly to women in the global south. In the case of countries such as Ethiopia the burden is internally borne by the poor and rural women.

The variables of being a wife, slave, and poor had been the triple, dual or single factors within the framework of the feminization of domestic work. But this does not imply the total exclusion of men from domestic work. It only shows how women dominate the job. For example, based on the 2005 estimation, $91 \%$ and $90 \%$ of the domestic workers are women in Ethiopia and Spain, respectively. ${ }^{24}$ As such, regulation of domestic work has a direct impact on the issue of gender. In particular, the type and extent of intervention can have positive or negative impacts on the social, economic and political lives of

${ }^{20}$ Andrea Cristina Mercado and Ai-jen Poo (2008), "Domestic Workers Organizing in the United States" The Association for Women's Rights in Development (AWID), Toronto, p. 5.

${ }_{21}$ Kidist Mulugeta (2012), Vulnerability, Legal Protection and Work Conditions of Domestic Workers in Addis Ababa (The Hague: International Institute of Social Studies Research Paper), p. 11.

${ }^{22}$ Andrea Cristina Mercado and Ai-jen Poo, supra note 20, p. 5.

${ }^{23}$ Premilla Nadasen and Tiffany Williams (2009), "Valuing Domestic Work" Barnard Center for Research on Women Vol. 5, pp. 3-6.

${ }^{24}$ ILO, supra note 7, pp. $34 \& 35$. 
female domestic workers. In other words, the application of gender mainstreaming in domestic work has important role in ensuring gender equality.

\subsection{Vulnerabilities, abuse, harassment and violence}

Domestic workers are among the most vulnerable groups to abuse, harassment and violence. The vulnerability of domestic workers can mainly be attributable to the relationship of submission, paternalistic view, low economic status, low level of education, nature of the work and isolation. ${ }^{25}$ Poor regulation of domestic work or lack of stipulated minimum legal standards of labour rights further exacerbate their exposure to abuse and violence. The ILO data, for example, indicate that domestic work continues to be one of the least protected groups of workers under domestic labour laws. The data also show very poor monitoring and implementation of existing laws thereby placing domestic workers in a highly disadvantaged position and exposing them to abuses and violence. ${ }^{26}$

In particular, domestic work is inherently isolated since it is carried out in the home of the employer. As a result, domestic workers tend to work in isolation and are invisible to the public. In most cases, the status relationship model advances acceptance to various abuses on the part of domestic workers. Besides, paternalistic approaches to domestic workers - which assume that poor women are assisted through the jobs, or that they are a member of the family encourage the exclusion of domestic workers from labour laws in many countries. ${ }^{27}$ Under such conditions of vulnerability, domestic workers face abuse, harassment and violence on continuous basis, which basically constitute violations of human rights.

A number of researches and reports conducted by ILO and NGOs in various countries, for example, reveal massive violation of human rights against domestic workers. These human rights violations are committed throughout the globe, although their degree may vary between countries. In spite of gaps in statistics and data, the limited research conducted in Ethiopia on the condition of domestic workers shows similarities with worldwide documented experience in the vulnerability and the type of abuse, harassment and violence committed against domestic workers. ${ }^{28}$ In her study on the condition of domestic workers in

${ }^{25}$ See, Ramirez-M. \& José M. (2003), Domestic Work, Conditions of Work and Employment: A legal Perspective (Geneva: ILO, Conditions of Work and Employment Series No. 7) p. 4.

${ }^{26}$ ILO, supra note 7.

${ }^{27}$ Ramirez-M. \& José M., supra note 25.

28 See, Elsa Biadegilegn (2011), "Conditions of Work for Adult Female Live-in Paid Domestic Workers in Addis Ababa, Ethiopia" Research and Perspectives on Development Practice, Kimmage Development Studies Centre, Dublin; and Kidest Mulugeta, supra 
Addis Ababa, Kidest Mulugeta, for example, indicated the existence of abuse, harassment and violence against domestic workers. ${ }^{29}$ Girma and Annabel also found that in a study of 2,000 commercial sex workers, 44\% were ex-domestic workers. $^{30}$

The most common reported forms of abuse, harassment and violence committed against domestic workers throughout the globe include ${ }^{31}$ labour exploitation and extreme restrictions on freedom. Domestic workers are required to work for long hours and perform heavy workloads. They face limited rest, sleep and leisure time, along with extreme restriction on freedom of movement and interference in personal matters as a result of the long hours at work and the close supervision by household members. The second form of abuse relates to inadequate conditions of accommodation which are common in domestic work. Domestic workers face denial of food and adequate living conditions. In many cases, domestic workers do not have their own room and are forced to sleep in store rooms, kitchen, on the corridor, or any other available space. Providing only leftovers or rotten food to domestic workers or depriving them of food as a punishment is very common.

Thirdly, sexual, psychological and physical abuses are widespread. Domestic workers face higher exposure to sexual harassment and rape, but in most cases they do not report against the employer's family members who abuse them because of the social stigma attached to it and the financial pressure to remain in the job. Moreover, frequent exposure to psychological abuse occurs in the form of punitive insults, intimidations and belittlement. These forms of abuse combined with excessive demands for work may push domestic workers - as was the case in certain Middle East countries - to suicide or to commit crimes

note 21, pp. 18-27; Annabel Eruikar and Tekle Ab Mekbib "Invisible and Vulnerable: Adolescent domestic workers in Addis Ababa, Ethiopia" Vulnerable Children and Youth: An international Interdisciplinary Journal for Research, Policy and Care, Volume 2, issue 3, 2007, pp. 246-256.

${ }^{29}$ Kidest Mulugeta, supra note 21.

${ }^{30}$ Girma W, Erulkar A (2009). "Commercial sex workers in five Ethiopian cities: A baseline survey for targeted HIV prevention for most-at-risk populations," Addis Ababa: Population Council Report.

${ }^{31}$ See, Human Rights Watch (2014), 'I Already Bought You' Abuse and Exploitation of Female Migrant Domestic Workers in the United Arab Emirate (United States: Human Rights Watch Publication); Varia Nisha (2008), As if I am not Human: Abuses against Asian Domestic Workers in Saudi Arabia (New York: Human Rights Watch Report Publications); Helen S. and Lisa-Marie Heimeshoff (edt.) (2011), Domestic Workers Counts: Global Data on an Often Invisible Sector (Kassel Germany: Kassel University Press; Kidist Mulugeta, supra note 21, pp. 18-27; and Elsa Biadegilegn supra note 28; and Interview conducted with Ato Wolde Asmelash a Domestic Workers Agent/Broker in Addis Ababa, Yeke sub-city, worda 02 (January 11, 2015). 
against the members of household motivated by revenge. In this regard, the 2012 Alem Dechasa suicide case can be cited as an example because it occurred in response to severe abuse and hurting insults by her employer in Lebanon. ${ }^{32}$ The types of abuse may include exposure to physical aggression ranging from slaps, pulling or cutting of hair, severe beatings, etc. that may be reactions of angry employers if a domestic worker executes orders too slowly, breaks something or forgets tasks. Such beatings may at times be done by drunk employers.

The fourth type of abuse refers to arbitrary changes of contracts and lack of benefits which are common in domestic work. Pay cuts or even non-payment of wages are facilitated by the irregular and invisible nature of the employment relationship. Lack of working benefits in domestic work is aggravated by the explicit exclusion of domestic workers from the scope of laws that grant protection including rights to reasonable wage, rest, leisure time, periodic paid leave, and prenatal and maternity leave. In many cases, situations such as sickness, injury, pregnancy or any temporary incapacity are common grounds for immediate dismissal.

\subsection{Domestic work and employers' problems}

Various problems are expressed by employers and employment agencies in relation to domestic work. ${ }^{33}$ First, there is general scarcity of domestic workers, both in terms of quantity and quality. Many families; particularly, couples who are employed or who undertake economic activities state the scarcity of domestic labour. This condition of scarcity discourages women from participating in the labour market. The main reason for the scarcity in labour market is that potential domestic workers do not want to engage in domestic work unless they are compelled by circumstances to do so. Many of them use domestic work as a stepping stone while searching for a better job or migration to the Middle East to work as a domestic worker. The current status shows that domestic work is not beneficial to them by all standards owing to low income and various forms of abuse. As such, potential domestic workers seek other options, such as working in cobblestone cooperatives, sanitary service, waitressing, daily labour at construction sites, or migration to foreign countries for domestic work.

32 The guardian, 'Alem Dechasa's choice: an impossible decision and a lonely death' $<$ www.thegaurdian.com/world/2012/apr/09/alem-dechasa-ethiopia-lebanon $>$ accessed on $6^{\text {th }}$ January 2015.

${ }^{33}$ Ato Wolde Asmelash a Domestic Workers Agent/Broker in Addis Ababa, Yeke Sub-city, Woreda 02 (January 11, 2015). and a personal communication with Vice Commander Zewdneh Kebede of Addis Ababa Police Commission (December 15, 2014). 
The second problem relates to crimes committed against family members or property of employers by domestic workers in Ethiopia, although it is low in magnitude. Particularly, domestic workers may commit theft and bodily injury. The causes of the commissions of these crimes are considerably attributed to the employers' mistreatment of their domestic workers. In most cases, the win-lose form of relationship exists between an employer and a domestic worker which may, at times, result in an illegal act of the domestic worker as a response to such relationship. The accumulated resentment towards employers rooted in being deprived of rest, food, human dignity, reasonable wage, leave, and other accommodations; or excessive beating, insulting, and belittling may create reactions from domestic workers in the form of crimes against employers. The inability of domestic workers to settle their problems fairly and equitably and their unmet expectations may cause loss of hope thereby leading to such offences. Nevertheless, there are instances where domestic workers may commit offences which are independent of the kind of treatment from employers.

Third, employers face instability of domestic work contract because of frequent turnover of domestic workers. Many domestic workers change place of work within a short period of time in search of a better satisfaction, mostly with the aid of brokers. Many employers fail to allow annual or monthly leave or do not accept the requests of domestic workers for educational opportunities under the perception that these rights or requests may put them under the risk of being deserted. Brokers may also exacerbate these conditions by facilitating instability of domestic work contracts through different means to benefit from new contracts. These problems persist in the context of the gaps in the regulation of the condition of domestic workers in Ethiopia.

\section{Legislative Response of the ILO and Some States to the Condition of Domestic Workers}

In June 2011, the International Labour Conference of the ILO adopted the 2011 Domestic Workers Convention No. 189 and the supplementing Recommendation 201 in response to the vulnerability of domestic workers to various forms of abuse. As of 5 September 2013, the Convention has entered into force after ratification by two states-Uruguay and Philippines. ${ }^{34}$ To date, twenty two ILO member states have ratified the Convention. ${ }^{35}$ This Convention is a very crucial

\footnotetext{
${ }^{34}$ ILO Press Statement, 05 September 2013 "Landmark treaty for domestic workers comes into force" $<$ http://www.ilo.org/global/standards/information-resources-andpublications/news/WCMS_220793/lang--en/index.htm> accessed on $20^{\text {th }}$ July 2016.

35 As of $16^{\text {th }}$ July 2016, twenty two states ratified the Convention, including South Africa, Paraguay, Panama, Bolivia, Chile, Colombia, Ecuador, Philippines, Guyana, Argentina, and Germany.
} 
instrument, because it is the first ILO convention that embodies specific labour standards dedicated to domestic workers.

The preamble of the Convention recognizes that "domestic work continues to be undervalued and invisible and is mainly carried out by women and girls, many of whom are migrants or members of disadvantaged communities", and states that they "are particularly vulnerable to discrimination in respect of conditions of employment and other violations of human rights". It also recognizes "the significance of domestic workers to the global economy which includes its contribution toward job opportunities for women and men workers with family responsibilities". It further notes the greater scope of domestic work "for caring of ageing populations, children and persons with disability", and with regard to "income transfers within and between countries". 36

The preamble further recalls the Universal Declaration of Human Rights (UDHR), the International Covenant on Civil and Political Rights (ICCPR), the International Covenant on Economic, Social and Cultural Rights (IESCR), the Convention on the Elimination of All Forms of Discrimination against Women (CEDAW) and other United Nations Human Rights Treaties. ${ }^{37}$ Article 3 of the Convention requires members to take measures to ensure the effective promotion and protection of human rights of all domestic workers, as set out in the Convention. In doing so, the Convention recognizes the interrelatedness and the mutually reinforcing objectives between the promotion and protection of human rights and ensuring decent working conditions for domestic workers.

Unless otherwise provided, all existing international labour conventions and recommendations apply to domestic workers. ${ }^{38}$ The Convention provides basic principles and measures regarding the promotion of decent work for domestic workers and binds states upon ratification. The accompanying Recommendation -which is not binding- offers practical direction for the consolidation of

$<$ http://www.ilo.org/dyn/normlex/en/f?p=1000:11300:0::NO:11300:P11300_INSTRUME NT_ID:2551460> accessed on $20^{\text {th }}$ July 2016

${ }^{36}$ See, Para $3 \& 4$ of the preamble to the 2011 Convention No. 189 on Decent Work for Domestic Workers.

${ }^{37}$ International Human Rights Conventions provide relevant rights to domestic workers. The UDHR, for example, recognizes the right to work; equal pay for equal work; just and favourable remuneration; rest and leisure; reasonable limitations of working hours as well as periodic holidays with pay (article $23 \& 24$ ). The ICESCR further develops the right to work and its essential result. The Convention elevates and highlights the right to just and favourable conditions of work and non-discrimination and equality (article 3, 6, $7 \& 8$ ). The CEDAW also stipulates that states shall take all appropriate measures to eliminate discrimination against women in the field of employment (article 11). Moreover, the ICCPR provides the right to form and join trade unions (article 22).

38 The preamble to the 2011 Convention No. 189 on Decent Work for Domestic Workers, paragraph 7 . 
domestic laws and policies on domestic work. The Recommendation comprises guidance on numerous issues not covered by the Convention, including matters on professional development of domestic workers, work-life balance, statistical data and international cooperation. ${ }^{39}$

Many countries have undergone similar changes at the level of legislation before and after the introduction of 2011 Domestic Workers Convention. In contrast, there are a number of states that still exclude domestic workers from labour laws. The following parts of this section highlight the main content of the 2011 Domestic Workers Convention, its supplementing Recommendation No. 201 and the legislative response of some foreign states to the condition of domestic workers.

\subsection{Written agreement}

Under the 2011 Domestic Workers Convention, member states are required to ensure that "domestic workers are informed of their terms and conditions of employment in an appropriate, verifiable and easily understandable manner and preferably, where possible, through written contracts in accordance with national laws, regulations or collective agreements" (article 7). In particular, this provision stipulates particulars to be reduced into written form such as (a) the name and address of the employer and of the worker; (b) the address of the usual workplace or workplaces; (c) the starting date and, where the contract is for a specified period of time, its duration; (d) the type of work to be performed; (e) the remuneration, method of calculation and periodicity of payments; (f) the normal hours of work; (g) paid annual leave, and daily and weekly rest periods; (h) the provision of food and accommodation, if applicable; (i) the period of probation or trial period, if applicable; (j) the terms of repatriation, if applicable; and $(\mathrm{k})$ terms and conditions relating to the termination of employment, including any period of notice by either the domestic worker or the employer. Recommendation No. 201 (Para. 6) further recommends members to provide appropriate assistance, when necessary, to ensure that domestic workers understand their terms and conditions of employment; particularly, to ensure the inclusion of job description; the rate of pay or compensation for overtime and standby; any payments in kind and their monetary value; details of any accommodation provided; and any authorized deductions from the worker's remuneration.

Likewise, South Africa's Sectoral Determination 7 section 9(1) requires comprehensive written particulars at the beginning of the domestic work employment relationship which is almost similar to the specific elements

${ }^{39}$ See Para 25(1)(2)(24) and 26(2)(4) of the Recommendation No. 201. 
described in the 2011 Domestic Workers Convention. The regulation has provided an annex model contract. ${ }^{40}$

\subsection{Fundamental principles and rights at work}

The 2011 Domestic Workers Convention requires member states, in relation to domestic workers, to take measures to respect, promote and realize the fundamental principles and rights at work, namely: (a) freedom of association and recognition of the right to collective bargaining; (b) the elimination of all forms of forced or compulsory labour; (c) the effective abolition of child labour; and (d) the elimination of discrimination in respect of employment and occupation (article 3(2)) as explained in the following subtopics:

\subsubsection{Freedom of association and the right to collective bargaining}

The Convention requires member states to ensure that domestic workers enjoy freedom of association and the right to collective bargaining. It also protects "the right of domestic workers and their employers to establish and - subject to the rules of the organization concerned- to join organizations, federations and confederations of their own choosing" (article 3(3)). Recommendation No. 201 (Para. 2) further recommends member states "to identify and eliminate any legislative or administrative restrictions or other obstacles to the right of domestic workers" so that they can "establish their own organizations" or "join the workers' organizations of their own choosing, as well as strengthen the capacity of workers' and employers' organizations".

Likewise, section 5.12 of Ireland's 2007 Code of Practice for Protecting Persons Employed in Other People's Homes ensures the rights of domestic workers to be entitled to the constitutional right of workers to decide whether to be represented by a union. It provides that "an employer shall not restrict the employee's right to trade union membership consistent with the employee's constitutional right to join or not to join a trade union". ${ }^{41}$

\subsubsection{Eradication of forced labour}

Forced or compulsory labour is defined as "all work or service which is exacted from any person under the menace of any penalty and for which the said person

${ }^{40}$ South Africa, Sectoral Determination 7: Domestic Worker Sector, $1^{\text {st }}$ September 2002. $<$ http://www.ilo.org/dyn/natlex/docs/SERIAL/74071/76138/F1095632950/ZAF-

74071.pdf $>$ accessed on $6^{\text {th }}$ January 2015.

${ }^{41}$ Ireland Industrial Relations Act 1990 (Code Of Practice For Protecting Persons Employed In Other People's Homes) (Declaration) Order 2007:

$<$ http://www.lrc.ie/documents/publications/codes/10PersonsEmployedinHomes.pdf $>$.

Accessed on $6^{\text {th }}$ January 2015. 
has not offered himself voluntarily". ${ }^{42}$ This provision is more relevant to domestic workers as the nature of domestic work is vulnerable to the possibility of compulsory or forced labour. Article (3)(2)(b)) of the 2011 Domestic Workers Convention requires measures to be taken to respect, promote and realize the elimination of all forms of forced or compulsory labour in relation to domestic workers. In particular, domestic work becomes forced labour in case of deception and false promises concerning conditions of work, lack of freedom to change employers, physical or sexual abuse, debt bondage, confiscation of identity papers, non-payment of wages, physical confinement and threat of denunciation or deportation. ${ }^{43}$ Recommendation No. 201 (Para 26(2)) recommends members "to cooperate at bilateral, regional and global levels for the purpose of enhancing the protection of domestic workers, especially in matters concerning the prevention of forced labour and trafficking in persons, and other matters".

In a similar manner, South Africa prohibits all forms of forced labour. South Africa's Sectoral Determination 7 section 23 which deals with the Prohibition of Child Labour and Forced Labour provides that "no person may, for his/her own benefit or for the benefit of someone else cause, demand or impose forced labour in contravention of the South African Constitution." Consequently, any form of forced labour entails criminal liability. Similarly, the United Republic of Tanzania's Employment and Labour Relations Act, 2004, which applies to domestic workers, treats forced labour as an offence, in sub-part B(6). ${ }^{44}$

\subsubsection{Abolition of child labour}

The UN Convention on the Rights of the Child sets out working conditions for children in order to protect them from economic exploitation and work that would interfere with their education, health and development (article 32). ${ }^{45}$ The Convention defines a child as "every human being below the age of eighteen years unless under the law applicable to the child, majority is attained earlier" (article 1). Legally, however, employment of persons under the age of eighteen in domestic work is not by itself a violation of the Convention, but amounts to child labour when the work is performed either by children below the legal minimum age for admission to employment or by children above the minimum

${ }^{42}$ Article 2(1) of the C29 Forced Labour Convention, 1930 Convention concerning Forced or Compulsory Labour.

${ }^{43}$ ILO: Report of the Committee of Experts on the Application of Conventions and Recommendations, Report III, (Part IA), International Labour Conference, $102^{\text {nd }}$ Session, Geneva, 2013, p. 240.

${ }^{44}$ United Republic of Tanzania, Employment and Labour Relations Act, 2004 $<$ http://www.ilo.org/dyn/travail/docs/2212/Employment\%20and\%20Labour\%20Relations $\% 20$ Act $\% 202004$.pdf $>$. Accessed on $5^{\text {th }}$ January 2015.

${ }^{45}$ The 1989 United Nations Convention on the Rights of the Child. 
age if such work amounts to a "worst form of child labour", for example, "hazardous work". 46

Accordingly, the 2011 Domestic Workers Convention requires member states to "set a minimum age for domestic workers consistent with the provisions of the Minimum Age Convention, 1973 (No. 138), ${ }^{47}$ and the Worst Forms of Child Labour Convention, 1999 (No. 182), and not lower than that established by national laws and regulations for workers generally" (article 4(1)). Members are required to take measures to "ensure that work performed by minors does not deprive them of compulsory education, or interfere with opportunities to participate in further education or vocational training" (article 4(2)).

Convention No. 189 and the Recommendation No. 201 (Para. 5(1)) identify hazards in domestic work and they prohibit domestic work for children under the age of 18, taking into account Convention No. 182 and its supplementing Recommendation No. 190. Likewise, the Zambian Minimum Wage and Condition of Employment (Domestic Workers) Order 2011 section 14 prohibits employment of a child as a domestic worker. ${ }^{48}$

\subsubsection{Elimination of discrimination in employment and occupation}

The 2011 Domestic Workers Convention requires member states to take measures "to eliminate discrimination against domestic workers in respect of employment and occupation, including payment, leave, remuneration, and working conditions" (article 3(2)(d)). Article 11 of the Convention, for example, requires member states "to take measures to ensure that remuneration is established without discrimination based on sex, in conformity to the provisions as set forth in the Equal Remuneration Convention, 1951 (No. 100)" "49, and the Discrimination (Employment and Occupation) Convention, 1958 (No. 111) ${ }^{50}$. In

46 The 1973 ILO C138 Concerning Minimum Age for Admission to Employment Convention provides that the minimum age for admission to employment or work shall not be less than the age of completion of compulsory schooling, and in any case not lower than 15 years.

${ }^{47}$ Ibid.

${ }^{48}$ Government of Zambia Statutory Instrument No. 3 of 2011, Minimum Wage and Condition of Employment (Domestic Workers) Order, 2011

$<$ http://www.ilo.org/dyn/natlex/docs/MONOGRAPH/86021/96725/F522992125/ZMB860 21.pdf $>$. Accessed on $6^{\text {th }}$ January 2015.

${ }^{49}$ C100 Equal Remuneration Convention, 1951 Convention concerning Equal Remuneration for Men and Women Workers for Work of Equal Value, $34^{\text {th }}$ Session, adopted on $29^{\text {th }}$ June 1951 and entered into force on $23^{\text {rd }}$ May 1953, Geneva, Switzerland.

50 C111 Discrimination (Employment and Occupation) Convention, 1958 Convention concerning Discrimination in Respect of Employment and Occupation, 42 ${ }^{\text {nd }}$ Session, adopted on $26^{\text {th }}$ June 1958 and entered into force on $15^{\text {th }}$ June 1960 , Geneva, Switzerland. 
taking measures for the elimination of discrimination, Recommendation No. 201 (Para. 3) also expects member states "to ensure that arrangements for workrelated medical testing respect the principle of the confidentiality of personal data and the privacy of domestic workers;" it also prevents any discrimination related to such testing.

Many states have taken measures to ensure that domestic workers are not discriminated in employment rights. The Zambian Minimum Wage and Condition of Employment (Domestic Workers) Order 2011, for example, provides detailed provisions on minimum wage and conditions of employment with regard to wage, hours of work, overtime, annual leave, paid sick leave, maternity leave and separation package in respect to domestic work. These rights ensure that domestic workers are not discriminated in employment rights and occupation.

\subsection{Abuse, harassment and violence}

Member states are required, under the 2011 Domestic Workers Convention, to take measures to ensure that domestic workers enjoy effective protection against all forms of abuse, harassment and violence. ${ }^{51}$ Recommendation No. 201 (Para. 7) also recommends members to establish accessible complaints mechanisms for domestic workers in reporting cases, to ensure the investigation and prosecution of all reported cases, and to establish programs for the relocation, temporary accommodation, health care, and rehabilitation of domestic workers subjected to abuse, harassment and violence.

The 2013 Philippines Domestic Workers Act No. 10361 article II section 5 provides standard of treatment to domestic workers. It stipulates that "an employer or any member of the household shall not subject a domestic worker to any kind of abuse, nor inflict any form of physical violence or harassment or any act tending to degrade the dignity of a domestic worker". ${ }^{52}$ Similarly, Ireland's 2007 Code of Practice for Protecting Persons Employed in Other People's Homes, section 5.2.1 provides that "the employer shall respect the dignity and privacy of the employee and shall take all steps necessary to safeguard the dignity and privacy of the employee working in the home."

\subsection{Decent working and living conditions}

The 2011 Domestic Workers Convention requires member states to take measures to ensure that "domestic workers, like workers generally, enjoy fair

\footnotetext{
${ }^{51}$ Article 5 of the 2011 Domestic Workers Convention.

${ }^{52}$ Republic of Philippines Domestic Workers Act No. 10361, 2013 $<$ http://www.gov.ph/downloads/2013/01jan/20130118-RA-10361-BSA.pdf $>$. Accessed on $5^{\text {th }}$ January 2015.
} 
terms of employment as well as decent working conditions and, if they reside in the household, decent living conditions that respect their privacy". 53 Moreover, states are required to take measures to ensure that domestic workers:

(a) are free to reach agreement with their employer or potential employer on whether to reside in the household;

(b) who reside in the household are not obliged to remain in the household or with household members during periods of daily and weekly rest or annual leave; and

(c) are entitled to keep in their possession their travel and identity documents. $^{54}$

As regards to food and accommodation, Recommendation No. 201 (Para. 17) recommends the need, taking into account national conditions, to have (a) a separate, private room that is suitably furnished, adequately ventilated and equipped with a lock, the key to which should be provided to the domestic worker; (b) access to suitable sanitary facilities, shared or private; (c) adequate lighting and, as appropriate, heating and air conditioning in keeping with prevailing conditions within the household; and (d) meals of good quality and sufficient quantity, adapted to the extent reasonable to the cultural and religious requirements, if any, of the domestic worker concerned.

Likewise, Section 6 of Zimbabwe Labour Relations (Domestic Workers) Employment (Amendment) Regulations, 2007 (No. 17) titled 'Accommodation, transport, lights and fuel', entitles a domestic worker who resides in the employer's premises "to free lodging, free water for basic domestic needs in or about the area of the premises, free lights and free fuel for cooking or, if no water, lights or fuel are provided, to the minimum monthly allowances specified in the Second Schedule in respect of water, light and fuel for cooking". 55

\subsection{Working time}

The 2011 Domestic Workers Convention requires member states:

to take measures toward ensuring equal treatment between domestic workers and workers generally in relation to normal hours of work, overtime compensation, periods of daily and weekly rest and paid annual leave in accordance with national laws, regulations or collective agreements, taking into account the special characteristics of domestic work. ${ }^{56}$

\footnotetext{
${ }^{53}$ Article 6 of the 2011 Domestic Workers Convention.

${ }_{55}^{54}$ Id., Article 9.

55 The Zimbabwe Labour Relations (Domestic Workers) Employment (Amendment) Regulations, 2007 (No. 17).

$<$ http://www.ilo.org/dyn/natlex/docs/ELECTRONIC/85412/95631/F544806888/ZWE85412.pdf>. Accessed on $5^{\text {th }}$ January 2015.

${ }^{56}$ Article 10(1)) of the 2011 Domestic Workers Convention.
} 
It provides that weekly rest shall be at least 24 consecutive hours. ${ }^{57}$ Besides, if a domestic worker works more than the normal working hours, there must be arrangement that could compensate the overtime. Recommendation No. 201 (Para 8-13) also recommends members "to establish an arrangement and standards for accurate recording of working hours, regulation of standby periods, night work, rest during the working day, weekly rest, compensatory rest, and annual leave."

South Africa's Sectoral Determination 7, section 10 regulates the daily and weekly normal hours of domestic workers. It also regulates maximum hours per day in accordance with the number of work days per week: "An employer may not require or permit a domestic worker to work more than (a) 45 hours in any week; and (b) nine hours on any day if the domestic worker works for five days or less in a week; or (c) eight hours in any day if the domestic worker works for more than five days in any week." Moreover, part D, section 12, provides for monetary compensation: it states that "an employer must pay a domestic worker at least one and one-half times the domestic worker's wage for overtime worked."

\subsection{Rest periods and breaks}

The 2011 Domestic Workers Convention requires member states "to treat domestic workers equally as other workers with respect to rest period and breaks periods of daily and weekly rest and paid annual leave" pursuant to "national laws, regulations or collective agreements, taking into account the special characteristics of domestic work" (article 10(1). It also sets obligatory weekly rest to be at least 24 consecutive hours (article 10(2)). Recommendation No. 201 (Para. 10) expects members to "ensure that domestic workers are entitled to suitable periods of rest during the working day."

With respect to break time, Zimbabwe's Labour Relations (Domestic Workers) Employment Regulations, 1992, section 5(3), provides that "no employer shall require or permit a domestic worker to work for a continuous period of six and a half hours without a meal-break of at least thirty minutes, a lunch break of at least one hour, and a tea break of at least fifteen minutes". ${ }^{58}$

\subsection{Night work}

On exceptional basis, a domestic worker may perform night work, for example, in cases of illness of a household member, or absence of parents, or other

\footnotetext{
${ }^{57}$ Id., Article 10(2).

${ }^{58}$ Zimbabwe's Labour Relations (Domestic Workers) Employment Regulations, 1992 $<$ http://www.ilo.org/dyn/natlex/docs/SERIAL/31951/27151/F1923737899/ZWE31951.pdf>. Accessed on $5^{\text {th }}$ January 2015.
} 
unforeseen situations. Article 10 of the 2011 Domestic Workers Convention stresses the need for equal treatment between domestic workers and other workers in regard to hours of work. In line with this, Recommendation No. 201 (Para. 9) provides for measures comparable to those aimed at avoiding protecting workers generally from the negative effects of standby work, including measures to establish a maximum number of permitted hours of night work, as well as rules regarding rest and remuneration. The Recommendation further recommends members to consider measures comparable to those specified in standby work. Several countries have also incorporated limits on night work into legislative and regulatory instruments specifically concerned with domestic workers. In some cases, a worker's consent is required or where no such requirement exists, the law places strict limitations on the circumstances in which such work may be imposed.

Zimbabwe's Labour Relations Employment Regulations, 1992, section 5(2), for instance, provides that "a domestic worker residing outside the premises of the employer shall not be required to work beyond 7:00 p.m." Similarly, South Africa's Sectoral Determination 7, section 13, provides:

an employer may only require or permit a domestic worker to perform night work, if agreed in writing and if (a) the domestic worker is compensated by the payment of an allowance; and (b) the domestic worker resides at the workplace or transport is available between the domestic worker's place of residence and the workplace at the beginning and end of the domestic worker's shift.

\subsection{Standby work}

The 2011 Domestic Workers Convention stipulates:

periods during which domestic workers are not free to dispose of their time as they please and remain at the disposal of the household in order to respond to possible calls shall be regarded as hours of work to the extent determined by national laws, regulations or collective agreements, or any other means consistent with national practice. ${ }^{59}$

Like that of night work, standby works are performed under exceptional circumstances where domestic workers cannot enjoy their rest period due to the accidental call of their employers. Recommendation No. 201 (Para. 9(1)) recommends states to regulate (a) the maximum number of hours per week, month or year that a domestic worker may be required to be on standby, and the ways they might be measured; (b) the compensatory rest period to which a domestic worker is entitled if the normal period of rest is interrupted by standby; and (c) the rate at which standby hours should be remunerated.

${ }^{59}$ Article 10(3) of the 2011 Domestic Workers Convention. 
South Africa's Sectoral Determination 7, section 14, defines standby as "any period between 8:00 pm and 6:00 AM the next day when a domestic worker is required to be at the workplace and is permitted to rest or sleep but must be available to work if necessary." According to this provision, an employer may only require or permit a domestic worker to be on standby if it is agreed in writing and if the domestic worker is compensated by the payment of an allowance of at least R20 per shift. Moreover, it prohibits an employer not to require or permit a domestic worker to be on standby more than five times per month or fifty times per year.

\subsection{Leave}

The 2011 Domestic Workers Convention requires member states to ensure equality of treatment between domestic and other workers with regard to paid annual leave in accordance with national laws, regulations or collective agreements, taking into account the special characteristics of domestic work. ${ }^{60}$ In addition, Recommendation No. 201 (Para. 13) states that "time spent by domestic workers accompanying the household members on holiday should not be counted as part of their paid annual leave." The right to paid annual leave and public holidays are important aspects of working time regulation in which they could provide domestic workers not only with necessary rest and leisure time, but also with an opportunity to attend to family responsibilities in particular and achieve a balanced lifestyle in general.

Similarly, article 21(1) of Zimbabwe's Labour Relations (Domestic Workers) Employment Regulations, 1992, states that "for the avoidance of doubt, every female domestic worker shall, in terms of section 19, of the Labour Relations Act, 1985, be entitled to maternity leave." Moreover, South Africa's Sectoral Determination 7 , section 21 , provides for five days of paid "family responsibility leave" in the event of childbirth, or illness or death of certain family members for domestic workers.

\subsection{Remuneration}

Regarding minimum wage and non-discrimination, the 2011 Domestic Workers Convention requires members "to take measures to ensure that domestic workers enjoy minimum wage coverage, where such coverage exists, and it provides that remuneration is established without discrimination based on sex". ${ }^{61}$ As noted earlier, the Equal Remuneration Convention, 1951 (No. 100), and the Discrimination (Employment and Occupation) Convention, 1958 (No. 111) also embody the same principle of non-discrimination in regard to

\footnotetext{
${ }^{60}$ Id., Article 10(1).

${ }^{61}$ Id., Article 11.
} 
remuneration. As regards the modalities for the payment of remuneration, the Convention provides that payments shall be made: (a) directly to the domestic worker, as opposed to a third party; (b) in cash; and (c) at regular intervals but at least once a month. ${ }^{62}$ It also establishes that national law, regulations, collective agreements or arbitration awards may allow the payment of a limited proportion of the remuneration in the form of payments in kind, but the monetary value attributed to such payments in kind must be fair and reasonable. ${ }^{63}$ Recommendation No. 201 (Para. 14, 15 and 20(3)) state the need to regulate payments in kind, statements of wages, prompt payment upon termination, and protection of worker's claims in case of employers' death or insolvency.

The Zambian Minimum Wage and Condition of Employment (Domestic Workers) Order 2011 section 5(1) provides that "the minimum wage of a domestic worker, excluding any amount paid in lieu of rations, shall not be less than two hundred and fifty thousand Kwacha per month." Moreover, section 5(3) stipulates that "the wage of a domestic worker shall be paid at regular intervals not later than five days after the date on which the wage shall fall due."

\section{Ethiopia's Response to the Condition of Domestic Workers}

Labour relations were regulated by various labour laws enacted in 1963 and 1975 until the 2003 Labour Proclamation was enacted thereby repealing the earlier proclamations and the provisions of the 1960 Civil Code that apply to labour relations. ${ }^{64}$ However, as stated earlier, the 2003 labour law excludes domestic workers from its scope of application. ${ }^{65}$ Yet, it states that the Council of Ministers shall issue a special regulation that deals with the condition of domestic workers. Subsequently, the 2003 labour law was partially amended by Proclamation No. 466/2005 and Proclamation No. 494/2006 in 2005 and 2006, respectively. ${ }^{66}$ But the amending Proclamations, said nothing about the issue of domestic workers.

ILO Conventions and the legislative response of various foreign states to the condition of domestic workers could be an opportunity for Ethiopia to

${ }^{62}$ Id., Article 12(1).

${ }^{63}$ Id., Article 12(1)(2).

${ }^{64}$ Labour Proclamation of the Federal Democratic Republic of Ethiopia No. 377/2003 (26 ${ }^{\text {th }}$ February 2004) Year 10, No. 12 Federal Negarit Gazeta (Addis Ababa) article 190(2)

${ }^{65}$ Id., Article 3(3)(c).

${ }^{66}$ Labour (Amendment) Proclamation of the Federal Democratic Republic of Ethiopia No. 466/2005 (30 $0^{\text {th }}$ June 2005) Year 11, No. 56 Federal Negarit Gazeta (Addis Ababa), and Labour (Amendment) Proclamation of the Federal Democratic Republic of Ethiopia No. $494 / 2006\left(29^{\text {th }}\right.$ June 2006) Year 12, No. 30 Federal Negarit Gazeta (Addis Ababa), respectively. 
benchmark best practices and thereby, issue a special regulation considering the context of Ethiopia. The exclusion of domestic workers from the 2003 labour law and failure to issue a special regulation based on the pledges made under the Labour Proclamation have allowed the continued application of the "1960 Civil Code ${ }^{67}$ with regard to the condition of domestic workers.

The 1960 Civil Code was considered modern during the period of its enactment as most of its provisions were transplanted from European codified laws with minor domestic contextualization. ${ }^{68}$ Nevertheless, internationally, domestic work was not treated as a real work and therefore, domestic workers were not at the time enjoying similar rights recognized for industrial workers. Moreover, the then Ethiopian feudal system with its deep-rooted values of hierarchy, obedience and subordination was not favourable to domestic workers. ${ }^{69}$ The provisions in the Civil Code that deal with labour relations between an employer and a domestic worker are therefore the result of the socio-political realities that prevailed in the 1960s.

The term domestic servant or in Amharic "sinhnc" refers to domestic worker under article 2601 of the Code which implied a negative pattern of relationship between an employer and a domestic worker. This term denotes a master and servant relationship. Yet, the operative provisions of the Code are not absolutely congruent with the term servant, although a master-servant model relationship can prevail in reality depending on the moral standards and character of the respective employers.

The general provisions of the contract of employment (arts 2512-2593) and the specific provisions (arts 2601-2604) provided under the 1960 Civil Code are applicable to the condition of domestic workers. Article 2514 provides that the general provision of the contract of employment shall apply to the domestic workers so long as the special provisions applicable to domestic workers do not cover the issue. But article 2601 makes this provision highly dysfunctional by empowering the employer to set standards in the regulation of the condition of domestic workers with regard to key issues such as housing, food, working time, and rest taking into account the domestic worker's health and well-being.

Article 2604 further impairs the condition of domestic workers by allowing the payment of wage to be effected every three months unless a shorter period is

${ }^{67}$ The Civil Code of the Empire of Ethiopia Proclamation No. $165 / 1960$ (5 $5^{\text {th }}$ May 1960) Year 19, No. 2 The Empire Extraordinary Negarit Gazeta (Addis Ababa) article 26012604.

${ }^{68}$ John H. Beckstrom (1973), "Transplantation of Legal System: An Early Report on the Reception of Western Laws in Ethiopia" American Journal of Comparative Law, Vol. 21, No. 3 p. 557-583.

${ }^{69}$ Christopher Clapham (2013), "The Ethiopian Experience of Devolved Government" Ethiopian Journal of Federal Studies Addis Ababa University Vol. 1, No. 1, p 18. 
agreed between the employer and domestic workers. The fundamental issues in labour relations such as working conditions, working time, wage, rest and leave enshrined under the general provisions of the contract of employment thus do not apply to domestic workers. The minimum working conditions and benefits enshrined under the Civil Code's general provisions of the contract of employment were considered inadequate and were, in effect, revised by the subsequent labour laws including the 2003 labour law. Owing to certain specific provisions of the Civil Code, domestic workers cannot, on the contrary, even invoke the rights stated under the general provisions of the contract of employment which have been regarded as inadequate to other workers.

This shows that the 1960 Civil Code has largely left the overall regulation of the condition of domestic workers to employers' sense of fairness rather than providing legally stipulated minimum working conditions and benefits. The existing relationship between an employer and a domestic worker exhibits a status, and not legal relationship based on rights and duties. Consequently, domestic workers are highly vulnerable to abuse, harassment and violence. Apparently, there are employers of domestic workers who do not have good moral judgment in setting the working time, food, rest, payment, and leave in respect to domestic work. The possibility for bad moral judgment thus constitutes a condition of vulnerability for domestic workers.

Nevertheless, this does not mean that domestic workers have no legal protection outside the Civil Code's provisions in their employment relations. As citizens or inhabitants, domestic workers have the right to be protected under the 2004 Criminal Code of Ethiopia. ${ }^{70}$ The Criminal Code, for example, has provided various criminal sanctions against criminal acts, including but not limited to crimes against life; morals, persons and health, honour, and bodily security. In particular, the Code provides protection to domestic workers from any possible sexual, physical and psychological abuses. Apart from the Criminal Code, domestic workers have the right to claim compensation for damage sustained while working for the employers under the law of extra-contractual liability. ${ }^{71}$ The Income Tax Regulations No. 78/2002 also exempts domestic workers from paying income tax. ${ }^{72}$

Yet the actual protection provided to domestic workers remains to be very limited unless domestic workers are included into the formal institution of labour laws. The existing laws cannot effectively and coherently address the

${ }^{70}$ A Proclamation of The Criminal Code of the Federal Democratic Republic of Ethiopia No.414/2004 ( $9^{\text {th }}$ May 2005) Separate Volume of the Federal Negarit Gazeta (Addis Ababa).

${ }^{71}$ Article 2028 of the 1960 Civil Code.

72 The Council of Ministers Income Tax Regulations No. 78/2002 (19 ${ }^{\text {th }}$ July, 2002) Year 8, No. 37 Federal Negarit Gazeta (Addis Ababa) article 3(g). 
vulnerability of domestic workers to various forms of abuses and violence. There is thus the need for legal regulation that deals with the form of contract, working hours, living conditions and accommodation, rest periods and breaks, leave, standby work, night work and remuneration. The alternative course of including domestic workers in the labour law regime can also provide effective and structured solution to the vulnerability of domestic workers as indicated in the experience of various foreign states.

\subsection{Reasons forwarded in favour of the status quo}

The FDRE Ministry of Labour and Social Affairs (MoLSA) is the responsible organ to propose a draft regulation on domestic workers. ${ }^{73}$ In fact, the Ministry has sent domestic workers' regulation draft proposal twice to the FDRE Prime Minister's Office of Legislative Drafting Department (PMOLDD) in 2012 and 2014. In both cases, however, the PMOLDD rejected the draft proposals arguing that further reconsideration of the issue is required. There are divergent ideas within MoLSA's departments or staff- on the immediate enactment of a domestic workers' regulation. While some support the immediate enactment of the regulation, others are in favour of delay in the issuance of the regulation. ${ }^{74}$

Similar arguments are forwarded by PMOLDD and MoLSA office holders who support delay in the enactment of the regulation. The reasons, inter alia, include, the need for proper timing, current gaps in the capacity of implementing the regulations, the need for safeguarding family cohesion and level of awareness. ${ }^{75}$ According to the pro-delay view, the first argument is that the time is not yet ripe to enact a special domestic workers' regulation because scientific research is required in the area that could balance both the interest of the employers and domestic workers. Promoters of this view contend that if it enacted, many employers would not be able to provide the benefits that would be accorded to domestic workers primarily due to their low capacity to pay. Second, they argue that MoLSA is not yet ready, both in terms of institutional and human resource capacity, to implement a domestic workers' regulation thereby rendering the regulation's effective implementation by MoLSA unlikely if it is immediately enacted.

Third, they argue that the prospective domestic workers' regulation may disrupt the traditional family-like relationship that exists between an employer and a domestic worker. They contend that most domestic workers are

73 A Proclamation to Provide for the Definition of Powers and Duties of the Executive Organs of the Federal Democratic Republic of Ethiopia No. 916/2015 (9th December 2015) Year 22, No. 12 Federal Negarit Gazeta (Addis Ababa) article 9(22) and 10(1)(a).

${ }^{74}$ Interview conducted with Ato Mengesha Mamo a Senior Legal Adviser of MoLSA $\left(14^{\text {th }}\right.$ December, 2014).

${ }^{75}$ Ibid. 
considered as a member of a family, not as workers; therefore, the prospective regulation would act against the interest of domestic workers when the familylike relationship gets threatened by the regulation, and this can nurture a confrontational relationship between an employer and a domestic worker. They think that domestic workers can get benefit more when they are treated as a family member of the employers rather than being treated as mere workers. Fourth, they point out the widespread unawareness of the reciprocal rights and duties of domestic workers and employers. According to supporters of delay in the enactment of the regulation, this gap in the level of awareness would undermine the implementation of the prospective regulation. ${ }^{76}$

Of course, scientific research is necessary to come up with a regulation that can effectively address the objective realities on the ground. However, MoLSA has not yet conducted the research, and about thirteen years have elapsed since the 2003 labour law's promise for a special domestic workers' regulation. MoLSA does not even know the number of domestic workers in Ethiopia let alone working towards research on the working conditions which involve various forms of abuse.

The issue of lack of capacity on the part of MoLSA and employers can indeed have a negative effect on the implementation of the prospective regulation. But this does not justify letting domestic workers bear the cost through hardships in their personal, social and economic lives. The regulation must be seen primarily from the angle of domestic workers. The human dignity of domestic workers must be the organizing principle in passing decisions or taking actions with respect to domestic work. The implementation of the prospective regulation can draw lessons from many African countries that have modern domestic workers' regulations. The most important aspect of the regulation is related with the need for behavioural change towards domestic work and domestic workers. Of course, the concern of employers and the government must be considered, as the very implementation of the regulation rests on these actors. However, the gaps in the capacity of these actors should not be exaggerated.

With regard to the argument that the regulation may have adverse impact on the family-like relationship between an employer and a domestic worker, it is to be noted that the prospective regulation will not come up with strange obligations that could offend employers or create onerous burden on them. It will merely embody obligations that are traditionally pursued by many conscientious employers in the course of fair treatment to their domestic workers. Employers who respect human dignity apparently allow sufficient and regular food, rest, and break; give reasonable payments for effort and work; and

\footnotetext{
${ }^{76}$ Ibid.
} 
they refrain from any abusive act towards domestic workers. The prospective regulation will only lay down minimum decent conditions under which an employer cannot provide less favourable conditions than what is provided. The regulation can indeed fulfil the mutual interest of employers and domestic workers, as there would be clarity of expectations from both sides. The parties to a domestic work contract would know exactly what to do and what to expect.

With regard to the widespread lack of awareness from the sides of employers and domestic workers, the way forward in solving the problem is not procrastination, but awareness creation. In fact, one of the very purposes of a law is to create awareness and regulate behaviour in line with the law.

\subsection{Other reinforcing reasons behind the procrastination}

Various reasons reinforce the tendency to keep the existing status quo. They are related with the prevailing attitude towards domestic work, the status of domestic workers and the existing legal environment. There are four major factors that contribute toward the sustenance of the status quo.

First, there are gaps in operative domestic and international NGO/CSOs to initiate and coordinate campaigns to end the government's procrastination in recognizing the rights of domestic workers or persuade the Ethiopian government to ratify the 2011 ILO Convention on domestic workers. Both domestic and foreign experiences demonstrate that $\mathrm{NGO} / \mathrm{CSO}$ are very important in assisting governments in the administration of public concerns ${ }^{77}$ In this regard, the achievements of the Ethiopian Women Lawyers Association (EWLA) in lobbying toward the amendment of the 1960 Civil Code concerning family matters, and its contribution during the revision of the 1957 Penal Code (in parts of the revision that relate to gender equality, prohibition of certain cultural practices, and increasing the penalties of sexual crimes) can be a good example. $^{78}$

Lessons can be drawn from the experience of foreign states. CHODAWU in Tanzania and the United House for Domestic Workers in Zambia, for example, together with their national trade union centers worked hard to influence their governments to raise the level of minimum wage for domestic workers. In Kenya, KUDHEIHA carried out a media campaign, and held public rallies and demonstrations, and was able to convince the National Social Security Scheme (NSSF) to come up with measures to collect social security contributions from

${ }^{77}$ ILO (2010), Decent Work for Domestic Workers: International Labour Conference, $\left(99^{\text {th }}\right.$ Session, Report IV(1)), (Geneva: ILO Publications), p. 83.

${ }^{78}$ Dessalegn Rahmato et al (2008) 'CSOs/NGOs in Ethiopia: Partners in Development and Good Governance,' A Report Prepared for the Ad Hoc CSO/NGO Task Force, Addis Ababa, p. 88. 
the employers of domestic workers. Other notable success has been also scored by the SYNTRAD in Guinea, CIAWU of Malawi, SADSAWU of South Africa, and SYNEHM in Benin in protecting the rights of domestic workers. ${ }^{79}$

Second, the 'Charities and Society Proclamation No. 621/2009'80 adversely affects the levels of engagement of existing and potential NGOs in the area of women's rights. The Proclamation, inter alia, excludes foreign NGOs from engaging in the promotion of human rights and the efficiency of the justice and law enforcement services. ${ }^{81}$ However, it allows, domestic NGOs to engage in these areas. Yet, it appears that domestic NGOs have resource and human constraints to fill these gaps. According to a research conducted in 2012, before the introduction of the Proclamation, EWLA, for example, had 65 full-time staff members and it conducted significant works in advocating gender mainstreaming in national legislation, providing legal aid to women, creating awareness-raising activities, and conducting researches on law and gender. In 2004 EWLA submitted a parallel report to the UN CEDAW. ${ }^{82}$

After the introduction of the Proclamation, EWLA has encountered constraints. There was thus a substantial reduction of employees and spheres of activities. The absence of comparable NGOs, which can work in the promotion of the rights of women both at the national and regional levels, has indeed exacerbated the problems. Such substantial reduction in EWLA's activities has negative implications for women's rights in Ethiopia, including the inclusion of gender considerations in new legislation, and wider advocacy of all rights of women including the rights of domestic workers. ${ }^{83}$ In the absence of alternative solutions, the Ethiopian government should thus proactively increase its efforts in the promotion of domestic workers' rights considering the gaps in $\mathrm{NGO} / \mathrm{CSO}$ activities in these pursuits.

Third, the general lack of attention over the issue of domestic workers provides opportunity for the reinforcement of the procrastination. The issue of domestic workers has received little attention from scholars, universities, NGOs and governmental institutions such as FDRE Human Rights Commission. There is very little consideration of domestic workers in scholarly researches and publications. Issues that relate to domestic workers are nearly absent from

${ }^{79}$ Vicky Kanyoka (2013) 'Item 4 (b): Report for the Africa Region, 2009-2013 International Domestic Workers Network (IDWN)' Montevideo, Uruguay, 26th-28th October 2013.

${ }^{80}$ Proclamation of the Charities and Societies of the Federal Democratic Republic of Ethiopia No. 621/2009 $\left(13^{\text {th }}\right.$ February 2009) Year 15, No. 25, Federal Negarit Gazeta (Addis Ababa).

${ }^{81}$ Id., Article 14(5).

${ }^{82}$ Amnesty International (2012), Stifling Human Rights Work: The Impact of Civil Society Legislation in Ethiopia (London: Amnesty International Publications), pp. 25-26

${ }^{83}$ Ibid. 
teaching materials in Ethiopian universities, research articles, and panel discussions. It can be said that researches on the area are almost exclusively foreign ones conducted by foreign scholars, universities, ILO, international NGOs - such as International Domestic Workers Network (IDWN) and Women in the Informal Economy: Globalizing and Organizing (WIEGO) that promote the rights of domestic workers. ${ }^{84}$

The programs of NGOs and governmental institutions in Ethiopia have not addressed the issue of domestic workers. The functions of EWLA, for example, have not been extended to address the issue of domestic workers. In most cases, its activities are limited to public sphere female workers, family issues and domestic violence. Likewise, the FDRE Human Rights Commission has never treated the issue of domestic workers in its works, including its extensive 2013 National Human Rights Action Plan. ${ }^{85}$

Fourth, the low economic, social and political status of domestic workers coupled with the invisible and isolated nature of domestic work exacerbates the silence of the government. As indicated in researches, domestic workers are overburdened with tasks; they live in poverty, have limited access to education, and are politically not active. ${ }^{86}$ Consequently, they could not have the necessary time, resource and skill to initiate, organize and campaign for their rights. Thus, a responsible top down stewardship intervention seems necessary to alleviate the problems of domestic workers.

\section{Instruments that Call for the End of the Procrastination}

As discussed in section 3, labour rights provided in the 2003 Labour Law have not been extended to domestic workers in Ethiopia. The inadequacies of the 1960 Civil Code are apparent due to the gaps in providing proper protection to domestic workers as enshrined mainly in the FDRE Constitution and

84 WIEGO (2015) "General Information on Worldwide Domestic Workers" $<$ http://wiego.org/informal-economy/occupational-groups/domestic-workers $>$ accessed on 24 January 2015

${ }^{85}$ The FDRE Human Rights Commission (2013), 2013-2015 National Human Rights Action Plan (Addis Ababa: Berilla Publishing); and discussion with various employees of the Commission. According to the employees, the Commission made a research in 2012 titled as 'Report on Human Rights Protection Monitoring in Ethiopian Prisons Primary Report Treatment of Prisoners,' and Rights of the Menjja Minority in Southern Region of Ethiopia this year.

${ }^{86}$ See, Yohannes Mersha Belete "Challenges and Opportunities of Female Domestic Workers in Accessing Education: A Qualitative Study of Bahir Dar City Administration, Amhara Regional State, Ethiopia" International journal of Sociology and Anthropology, 2014 Vol. 6(6); Adamnesh Atnafu, et al, supra note 12; Kidest Mulugeta supra note 21; and Elsa Biadegilegn supra note 28. 
International Human Rights instruments. In particular, the Code cannot fulfil and protect the equal protection under the law, reasonable limitation of working hours, rest and leisure times, periodic paid leave, remuneration for public holiday, and healthy and safe working environment, and just and favourable remuneration. The regulation that was envisaged in the 2003 Labour Law with regard to a regulatory framework for domestic workers is thus indispensable.

In spite of these gaps, the 1995 FDRE Constitution ${ }^{87}$, the 1993 Ethiopian National Women Policy (ENWP), Ethiopian's Growth and Transformation Plans (GTP), the Commitments under Post-2015 Sustainable Development Goals (SDGs), the Universal Declaration of Human Rights (UDHR), and various international instruments to which Ethiopia is a party require the Ethiopian government, directly or indirectly, to end the procrastination in recognizing the right of domestic workers in Ethiopia. ${ }^{88}$

The FDRE Constitution provides human rights as its major pillar. It is the supreme law of Ethiopia ${ }^{89}$ and obliges all citizens, organs of state, political organizations, etc... to respect and obey it. ${ }^{90}$ It further declares that human rights and freedoms, emanating from the nature of mankind, are inviolable and inalienable. ${ }^{91}$ To this end, it imposes a special obligation on the legislative, executive and judicial organs of federal and regional states to respect and enforce human and democratic rights. ${ }^{92}$ It also provides that the rights enshrined in the Constitution ought to be interpreted in conformity with the international human rights treaties. ${ }^{93}$

The Constitution provides relevant and applicable rights to domestic workers. In particular, the Constitution recognizes the right to security of the person (article 16); freedom from inhuman treatment, slavery, and forced labour (Article 18); honour and reputation (Article 24); equal protection under the law (article 25); reasonable limitation of working hours, rest, periodic paid leave,

${ }^{87}$ A Proclamation of the Constitution of the Federal Democratic Republic of Ethiopia No. 1/1995 (21 August 1995) Year 1, No. 1 Federal Negarit Gazeta (Addis Ababa).

88 The instruments include: African Charter on Human and Peoples' Rights on the Rights (ACHPA), African Charter on the Rights and Welfare of the Child (ACRWC), International Covenant on Civil and Political Rights (ICCPR), International Covenant on Economic, Cultural and Social Rights (ICECSR), Convention on the Rights of the Child (CRC), and Convention on Eliminating All Form of Discrimination Against Women (CEDAW) and a number of ILO Labour Conventions.

See The FDRE Human Rights Commission (2013) The 2013-2015 National Human Rights Action Plan (Addis Ababa: Berilla Publishing) p. 129

${ }^{89}$ FDRE Constitution, supra note 87, Article 9(1).

${ }^{90}$ Id., Article 9(2).

${ }^{91}$ Id., Article 10(2).

${ }^{92}$ Id., Article 13(1).

${ }^{93}$ Id., Article 13(2). 
remuneration for public holiday, and healthy and safe working environment (article 42(2)); and freedom of association for any cause or purpose (article 31). The latter right is further specified under Article 42(1)(a) which recognizes the right of workers to form associations for the purpose of improving their economic and employment conditions including the right to form trade union and other associations, and negotiate with their employers and other organizations affecting their interests.

Under the heading of the rights of women, the Constitution recognizes the equality of women and men in the enjoyment of rights and protection (article $35(1)$ ), particularly in employment, promotion, pay and the transfer of pension entitlements (article 35(8) \& 42(1)(d)); entitlement of women to affirmative action to rectify past discrimination and marginalization, and thereby, to achieve substantive gender equality (article 35(3)); and the right of women to paid prenatal and maternity leave (article 35(4)(a)(b)). The Constitution prohibits the laws, custom, and practices that oppress or cause bodily or mental harm to women. $^{94}$ Moreover, the Constitution recognizes the rights of children "not to be subject to exploitative practices, and they can neither be required nor permitted to perform work which may be hazardous or harmful to their education, health or well-being". 95 The 'principle of best interest of the child' is expected to constitute the organizing principle for legislative, administrative and judicial decisions while working on children issues. ${ }^{96}$

The 1993 Ethiopian Women Policy has the objective of, inter alia, "facilitating conditions conducive to the enhancement of equality between men and women so that women can enjoy human rights on equal terms" which include benefits "from the fruits of their labour; access to basic social services such as education, health, as well as minimizing their workload, and eliminating male supremacy, prejudices and discriminatory customary practices". ${ }^{97}$ Similarly, Ethiopia's Growth and Transformation plans set out the objective of ensuring women's active participation in social, economic, and political process and enabling them to be beneficiary from the resultant outcome; the plans further envisage the abolition of harmful traditional practices that adversely affect the active engagement and welfare of women. ${ }^{98}$ Even though policies and development plans do not contain specific programs with regard to female

\footnotetext{
${ }^{94}$ Id., Article 35(4).

${ }^{95}$ Id., Article 36(1)(d).

${ }^{96}$ Id., Article 36(2).

${ }^{97}$ Sosena Demessie and Tsahai Yitbark (2008), "A Review of National Policy on Ethiopian Women," in Taye Assefa (eds) Digest of Ethiopia's National Policies, Strategies and Programs (Addis Ababa: Forum for Social Studies), p. 96.

98 See, for example, FDRE Ministry of Economic Development and Finance (2010), The 2010-2015 Growth and Transformation Plan (Addis Ababa, Volume I), pp. 110-111.
} 
domestic workers, it can be presumed that the instruments are also applicable to domestic workers.

Ethiopia had commitments under the 2000 UN Millennium Declarations Resolution with respect to MDGs to eliminate gender disparity in education, employment and political participation as well as eradicate extreme poverty and hunger by $2015 .{ }^{99}$ This commitment has also continued under the UN Post-2015 Sustainable Development Goals, and Goal 5 aspires to "achieve gender equality and empower all women and girls".

Regional and international human rights treaties have set out standards with respect to the right to work that are applicable to domestic workers. The UDHR, for example, recognizes the right to work; equal pay for equal work; just and favourable remuneration; rest and leisure; reasonable limitations of working hours as well as periodic holidays with pay (article $23 \& 24$ ). The ICESCR further develops the right to work and its essential result. The Convention embodies the right to just and favourable conditions of work and nondiscrimination and equality (article $3,6,7 \& 8$ ). The CEDAW also stipulates that states shall take all appropriate measures to eliminate discrimination against women in the field of employment (article 11). Moreover, the ICCPR provides the right to form and join trade unions (article 22).

Both the CRC and ACRWC (under articles 32 and 15, respectively) provide for work conditions for children that protect them from economic exploitation and from work that would affect their education, health, physical, mental, spiritual, moral, and social development. Moreover, the ACHPR provides that "every individual shall have the right to work under equitable and satisfactory conditions, and shall receive equal pay for equal work" (article 15). Notably, the ILO organization which promotes the motto that declares 'labour should not be regarded as a commodity' has adopted several labour rights conventions such as the ILO 100 equal remuneration, ILO 111 non-discrimination, ILO 87 and ILO 98 freedom of association, ILO 29 and ILO 105 prohibition of forced labour, ILO 138 minimum age, and ILO 182 elimination of the worst forms of child labour which are applicable to domestic workers.

\section{Concluding Remarks}

Unlike the ILO Domestic Workers Convention and the laws of various foreign states, Ethiopia has not extended regular labour rights to domestic workers. This renders the 1960 Civil Code applicable to domestic workers. The Civil Code largely allows employers to regulate the condition of domestic workers, without

99 The 2000 United Nations Millennium Declaration on MDG which further reviewed during the General Assembly 2005 World Summit Outcome, 16 September 2005, Sixtieth session Agenda items 46 and 120. 
setting legally stipulated minimum working conditions. The Code, in effect, advances status based relationship, as opposed to legally defined rights and obligations.

The Code does not provide legal protection unless the employer voluntary acts fairly towards a domestic worker. It cannot thus address vulnerabilities of domestic workers to various abuses, and cannot improve the working conditions of domestic workers. In the other words, lack of legal standards in the Code has negative impact on gender equality as the area has been dominated by female workers. In effect, domestic workers could not have secure lifestyle that facilitates personal development, active community involvement, and economic empowerment, because the status relationship deprives them the necessary rest, leave, education, and finance. Due to the unaddressed vulnerabilities of domestic work or the inadequate legal protection provided by the Code, domestic work tends to encourage a win-lose model of relationship between employers and domestic workers. As a result, employers are facing several problems such as exposure to crimes, inadequate access to domestic workers' market, and frequent change of contracts.

The inclusion of domestic workers in the formal labour market through the issuance of the domestic workers' regulation can, inter alia, address the vulnerability of domestic workers to various forms of abuse. Setting out minimum legal standards of reciprocal labour rights and duties can proactively prevent abuses and bring transparency and accountability by subjecting this sphere of employment to public oversight and monitoring. The issuance of the regulation will create conducive and decent working conditions for domestic workers and can facilitate a win-win relationship between employers and domestic workers. This enables domestic work to attract potential workers as well as create more peaceful relationship and stability of contracts. In the process, employers will also benefit from the stability, peaceful relationship and availability of domestic workers.

Despite the negative effects of the gaps in the existing law, there is procrastination to recognize the rights of domestic workers. This is contrary to the obligation of the government under the FDRE Constitution and International Human Rights Instruments to which Ethiopia is a party. From both national and international perspectives, the Ethiopian government is therefore required to recognize the equality of domestic workers with other workers in terms of various interests and enact domestic workers' regulation.

The Council of Ministers should promptly issue a special regulation of domestic workers as envisaged in article 3(3)(c) of the 2003 labour law, by taking the 2011 ILO Domestic Workers Convention as a general model. The prospective regulation should mark a shift from sole reliance on employers' sense of fairness towards employment rights. In doing so, the human dignity of domestic workers should serve as a point of reference. 
Moreover, it is highly recommended that Ethiopia ratify the 2011 ILO Domestic Workers Convention. Ratification of the Convention can help Ethiopia to act more responsibly towards domestic workers and receive experience and technical assistance. Eventually, the enactment of domestic workers' regulation will minimize the vulnerability of domestic workers to various abuses. It can also provide stability of contract and availability of more domestic workers to the mutual advantage of domestic workers and employers.

To this end, the FDRE Human Rights Commission, individuals, scholars, universities and NGOs should shoulder a special stewardship obligation in promoting the rights of domestic workers and accentuating the importance of domestic work to social and economic life of the Ethiopian society. These actors should work towards discarding the latent prejudice over domestic work since the issuance of a regulation cannot be a panacea per se to the problems of domestic workers unless it is accompanied by an attitudinal change on the part of employers. 